\title{
Stock Volatility around Bank merger announcements: Evidence from India
}

\author{
V.Srividya ${ }^{1}$, Shripria $^{2}$, J. Sekkizhar $^{3}$, S.Raksha $^{4}$ \\ \{ srividya@psgim.ac.in ${ }^{1}$, shripria@kctbs.ac.in ${ }^{2}$, sekkizhar@psgim.ac.in ${ }^{3}$, raksha.s94@gmail.com ${ }^{4}$ \} \\ ${ }^{1}$ Professor, PSG Institute of Management, PSG College of Technology, ${ }^{2}$ Professor, KCT Business School, \\ ${ }^{3}$ Associate Professor, PSG Institute of management, PSG College of Technology, ${ }^{4}$ PG Student, PSG Institute \\ of Management, PSG College of Technology, Coimbatore
}

\begin{abstract}
This study examines the effect of bank merger announcements during post liberalization regime in India based on stock return and stock volatility. A Sample of 24 merger announcements from 2000 to 2019 among Indian banks are examined over an event window of 500 days. The GARCH model is used to analyze the volatility of stock returns around the announcement of mergers. This study examines the changes occurring in the acquiring banks on the basis of Stock price volatility exploring the idea of how an investor can earn the returns against the market. The findings show possibility of positive returns for shareholders of acquiring banks after the mergers.
\end{abstract}

Keywords: Merger, acquisition, Volatility, Stock return, merger announcement

\section{Introduction}

Bank mergers are aimed at economies of scale, efficiency, reduction in costs, diversifying risk or other benefits. The mergers of banks and financial institutions are notably high during or after crisis such as the Asian financial crisis and the financial crisis. It is held that any uncertainty nationally or internationally would jeopardize the banking sector leading to failures and crisis. The banking system in India has been transformed due to the reforms in the post liberalization era. Merger of banks has been considered as a measure to strengthening the sector. The Government believed the merger would revive and revitalize the banking sector. Mergers are expected to increase operational efficiency and helps banks lower their costs, thus enabling them to lower their lending rates.

The merger of the Indian public sector banks has reduced the number of state-owned banks in the country from 27 (in 2017) to 12 (in 2019). The announcement of the merger and recapitalization of the banks during an economic slowdown has shaken the investor confidence and caused volatility in the bank's stocks. Volatility however is a double-edged sword and the investors sentiment on various merger is different. This study aims to investigate the effect of bank mergers announced in India after 2000. A study on the effects of merger announcements on stock return and volatility of Indian bank's stock would help the investors to choose the stocks appropriately and help them yield higher returns. 


\section{Literature Review}

The studies on merger of banks in India focus on financial performance using accounting ratios, cash flows, NPA and CAMEL model. Khan (2011), Rao \& Kumar (2013) and Gurbaksh Singh, Sunil Gupta (2015) studied the merger effects on the performance of Banks under various time periods from 2001 to 2015 and concluded the positive impact of merger and increased performance. Singh \& Das (2018) studied the benefits of merger between Bank of Rajasthan and ICICI Bank. Radha Naga \&Tabassum (2014) evaluated the performance of two banks and found contradicting results about the post - merger performance. Tandon, et al. (2019) studied the merger of SBI and its associates and concluded that the merger did not give immediate results. In yet an other study of SBI mergers, Khan \& Zia (2019) using a 300 day event window studied the volatility with GARCH model and concluded that mergers caused high volatility in stocks. Tanwar (2016) and Sahni\&Gambhir (2018) used CAMEL model to analyze the difference in performance of few select banks before and after a merger and found significant differences in the performance. Bhattacharyya \&Chatri (2012) analyzed the performance of 15 commercial banks that were merged during the post reform period( 2000 to 2010). Kuriakose\& Paul (2016) in their study on post-liberalization bank mergers $(2000-2011)$ had pointed out the reasons for the existence of adverse post-merger performance in few cases, to be due to dissimilarity among banks in most of the key areas. Khan \&Ikram (2012) examined bank mergers from 2003 to 2009 and Abhishek Kumar (2013) from 2004 to 2010 using the Standard Event Study Methodology . Their study confirmed the possibility of earning excess return before and after the announcement. The efficiency of the stock market in the semi-strong form was also proved. Shah and Deo (2013) using a sample of 17 merger found evidence of significant impact of bank mergers on bidder portfolio. Mall \& Gupta (2019) have examined 383 mergers and acquisitions during 2000-2018 of stocks listed on NSE concluded that positive abnormal returns and wealth were possible for the shareholders after the mergers.

Studies of bank mergers and acquisitions from across the world using various methodologies have documented varied results. Schiereck et al., (2009) studied mergers in Europe announced between 1997 and 2002. The study using a large sample of 285 found that the shareholder's wealth was not significantly affected by Merger and Acquisitions.

Tan \&Hooy (2004) studied the volatility before and after the merger announcement of four anchor banks in Malaysia using EGARCH model and found the stock prices and returns had improved as a result of the merger. Pessanha et al. (2016) conducted a study on merger of banks in Brazil using GARCH model during the time period 1994-2015 and concluded that the market reaction to the mergers were based on the bank's reputation.

In general, the studies on merger of banks analyses the effect of mergers on stock prices, volatility and the synergy effects. The studies using accounting information to compare performances before and after merger, follow various methodologies like ratios, CAMEL, DEA. The disadvantage of these studies is that they use accounting data which are historical and often ignores the market value.

Study of the behavior of returns around the merger announcement and the reaction of the market to the announcement of the mergers based on the assumptions of EMH [Shah 2013; Patel and Shah 2016]. Evidence from research on mergers shows mergers are aimed at restructuring and 
improving the efficiency of banks and usually larger profitable banks acquire weaker ones. (Caiazza et al. 2014). There are number of studies investigating the bank efficiency (Ankit 2012, Bhattacharyya 2012), performance (Deepak 2018), volatility of stock price (Patel and Shah 2016, Khan and Zia 2018) and profitability (Singh and Gupta, 2015) following merger and acquisition. However they cannot be generalized and no meaningful conclusions can be drawn from them as they use different methodologies and are conducted in different time periods.

\section{Research Gap and Objective of the Study}

The market is expected to react at the time of announcement or arrival of any new information (Beaver, 1968). The speed with which information has been assimilated and reflected in prices can be examined using volatility (Louhichi, 2008). The variability in prices due to unexpected information is defined as volatility (Slimane, 2012). The shareholders expect an increase in volatility on the announcement of consolidation event but, in the post-event period, volatility comes down when market is efficient and has fully absorbed the information. (Kumar et al. 2013). Any announcement can lead to changes in investors expectation and hence a revision in their portfolios.

In India there has been a recent increase in the mergers of financial institutions, hence the wealth effects and stock volatility around M\&A in short run would be of interest to investors. In developed markets a number of studies have been conducted and literature on M\&A is available.

Despite having fewer studies in India the empirical evidence on its effects are inconclusive (Rani et al 2015, Khan \& Zia 2018). These mixed results make it complex to generalize (Rani et al., 2015). Therefore, this study aims to analyze the impact of bank merger in India during the post reform period on stock return and volatility; it would provide insights into post-merger wealth effects for Investors.

The objective of the study is to analyze the impact of merger announcements on the stock price and to examine the stock volatility of acquirer banks during post liberalization regime.

\section{Methodology}

The Indian banks that merged during the post liberalization period (i.e) after 2000 till 2019 were considered for the study. Of the 25 mergers 19 banks were selected as sample based on the availability of acquirer bank's stock price. The sample of the mergers with date of announcement is presented in Table 2 .

The event day is the date of announcement of merger and is treated as independent variable and the stock return and stock volatility are taken as dependent variable. The event window is a period of 500 days, the announcement day is taken as day 0 and the period is equally split as $-/+$ 250 days before and after announcement day respectively. The daily closing stock price for the event period has been collected from National Stock Exchange (NSE) and yahoo finance.

GARCH $(1,1)$ model used popularly for a single time series is employed using R software 
The model, is given as:

$$
\sigma_{i}^{2}=a_{n}+a_{1} u_{t-1}^{2}+\beta_{i} \sigma_{t-1}^{2}
$$

Alpha - arch effect - past error is influencing more on the present conditional variance; Beta - previous variance on present variance.

The conditional variance at a time ie.u at a particular time depends on the conditional variance of the previous time ( $\mathrm{t}-1)$ period and also on the squared error term in the previous $(\mathrm{t}-1)$ period. This model considers current volatility is influenced by past innovation to volatility. When volatility is high prices may can move in either direction (khan, 2018). This model predicts volatility of the stock returns around the merger and can be used to measure the efficient market hypothesis $(\mathrm{EMH})$ which proposes that a security completely and fairly displays all available and relevant facts. Consequently, the price will change only while new information is released (Mueller \&Sirower, 2003)

\section{Results and Analysis}

The persistence of a GARCH model indicates the speed with which volatility dies after the announcement. The value of the variance parameters alpha and beta should be low, i.e $\alpha 1+\beta 1<1$

When $\alpha 1$ is large the volatility reaction is intense and when $\beta 1$ is large then the shocks to conditional variance takes longer to die which suggests the persistence of volatility.

If $\alpha 1$ is relatively high and $\beta 1$ is low then volatilities tend to have a greater 'spike', if $\alpha 1$ is relatively low and $\beta 1$ is high then volatilities show low 'spike'. If the sum of alpha and beta parameters is greater than one then volatility is considered to be explosive and if equal to one

exponential. The stock returns for 250 days before and for 250 days after the announcement of merger are calculated and analyzed using $\operatorname{GARCH}(1,1)$ model.

Out of 19 bank merger and acquisition, 17 acquirer banks have higher $\beta 1$ suggesting the persistence of volatility, as the shocks to conditional variance take a long time to die out. When $\beta 1$ is notably higher than $\alpha 1$, greater spikes are observed. So, in these banks volatility of stock price is affected by merger announcements as they take long time to return to normal. The investors can use these acquiring banks stocks to earn higher return if they invest at the right time. The acquirer banks which come under the above category are as follows.

\begin{tabular}{|l|l|l|l|l|}
\hline \multicolumn{1}{|c|}{ Acquiring Bank } & \multicolumn{1}{|c|}{ Target Bank } & \multicolumn{1}{c|}{$\begin{array}{c}\text { Date of } \\
\text { Announcement }\end{array}$} & \multicolumn{1}{c|}{$\boldsymbol{\alpha 1}$} & $\boldsymbol{\beta 1}$ \\
\hline $\begin{array}{l}\text { Oriental Bank of } \\
\text { Commerce }\end{array}$ & Global Trust Bank & 26-Jul-04 & 0.000 & 0.999 \\
\hline IDBI Ltd & IDBI Bank & 29-Jul-04 & 0.000 & 0.999 \\
\hline Punjab National Bank & Nedungadi Bank Ltd. & 17-Dec-04 & 0.289 & 0.661 \\
\hline Federal Bank & Ganesh Bank of Kurandwad & 6-Jan-06 & 0.343 & 0.627 \\
\hline $\begin{array}{l}\text { Centurion Bank of } \\
\text { Punjab }\end{array}$ & Lord Krishna Bank & 1-Apr-06 & 0.189 & 0.429 \\
\hline IDBI Ltd & United Western Bank & 12-Sep-06 & 0.046 & 0.847 \\
\hline ICICI Bank Ltd & Sangli Bank & 12-Dec-06 & 0.208 & 0.718 \\
\hline
\end{tabular}




\begin{tabular}{|c|c|c|c|c|}
\hline Indian Overseas Bank & Bharat Overseas Bank & 9-Apr-07 & & \\
\hline State Bank Of India & Swarastra Bank & 27-Aug-07 & & \\
\hline HDFC Bank & Centurion Bank of Punjab & 5-Feb-08 & 0.135 & 0.808 \\
\hline State Bank Of India & State Bank Of Indore & 19-Jun-09 & 0.104 & 0.848 \\
\hline ICICI Bank & Bank of Rajasthan Ltd. & 19-May-10 & 0.035 & 0.941 \\
\hline $\begin{array}{l}\text { Kotak Mahindra } \\
\text { Bank }\end{array}$ & ING Vyasa Bank & 20-Nov-14 & 0.000 & 0.996 \\
\hline & $\begin{array}{l}\text { BharatiyaMahila Bank } \\
\text { (BMB) }\end{array}$ & \multirow{6}{*}{ 15-Jun-16 } & 0.000 & 0.999 \\
\hline & $\begin{array}{l}\text { State Bank of Travancore } \\
\text { (SBT) }\end{array}$ & & 0.166 & 0.734 \\
\hline \multirow[t]{4}{*}{ State Bank of India } & $\begin{array}{l}\text { State Bank of Bikaner and } \\
\text { Jaipur (SBBJ) }\end{array}$ & & 0.020 & 0.928 \\
\hline & $\begin{array}{l}\text { State Bank of Hyderabad } \\
(\mathrm{SBH})\end{array}$ & & 0.000 & 0.997 \\
\hline & $\begin{array}{l}\text { State Bank of Mysore } \\
(\mathrm{SBM})\end{array}$ & & 0.000 & 0.995 \\
\hline & State Bank of Patiala (SBP) & & 0.000 & 0.996 \\
\hline Bank of Baroda & Vijaya bank, Dena bank & 1-Sep-18 & 0.020 & 0.928 \\
\hline Punjab National Bank & $\begin{array}{l}\text { Oriental Bank of Commerce } \\
\& \text { United Bank of India }\end{array}$ & 30-Aug-19 & 0.000 & 0.997 \\
\hline Canara Bank & Syndicate Bank & 30-Aug-19 & 0.000 & 0.995 \\
\hline Union Bank of India & $\begin{array}{l}\text { Andhra Bank \& Corporation } \\
\text { Bank }\end{array}$ & 30-Aug-19 & 0.000 & 0.996 \\
\hline Indian Bank & Allahabad Bank & 30-Aug-19 & & \\
\hline
\end{tabular}

Table 1.Post-merger announcement period, analysis

The below chart shows the return of Punjab National Bank, as soon as the merger was announced, from day 210 there is higher volatility, which is much similar to GARCH $(1,1)$ model interpretation with $\beta 1$ of 0.9973 . Even though the amalgamation would create country's second largest bank, it is observed that there is a negative impact in merger announcement of PNB, OBC and UB as there is a raise in stock returns. The negative impact could be due to the capital infused by the government in Punjab National Bank to the extent of Rs.160 Billion which is the highest amount of capital among other banks. This impact was short term since the investors saw the pressure on profitability and the lack of clarity on merger ratio also led them to move out of the PSU banks. As the merger announcement was made in 30th August, 2019 the analysis was conducted only for 350 days instead of 500 days event window 


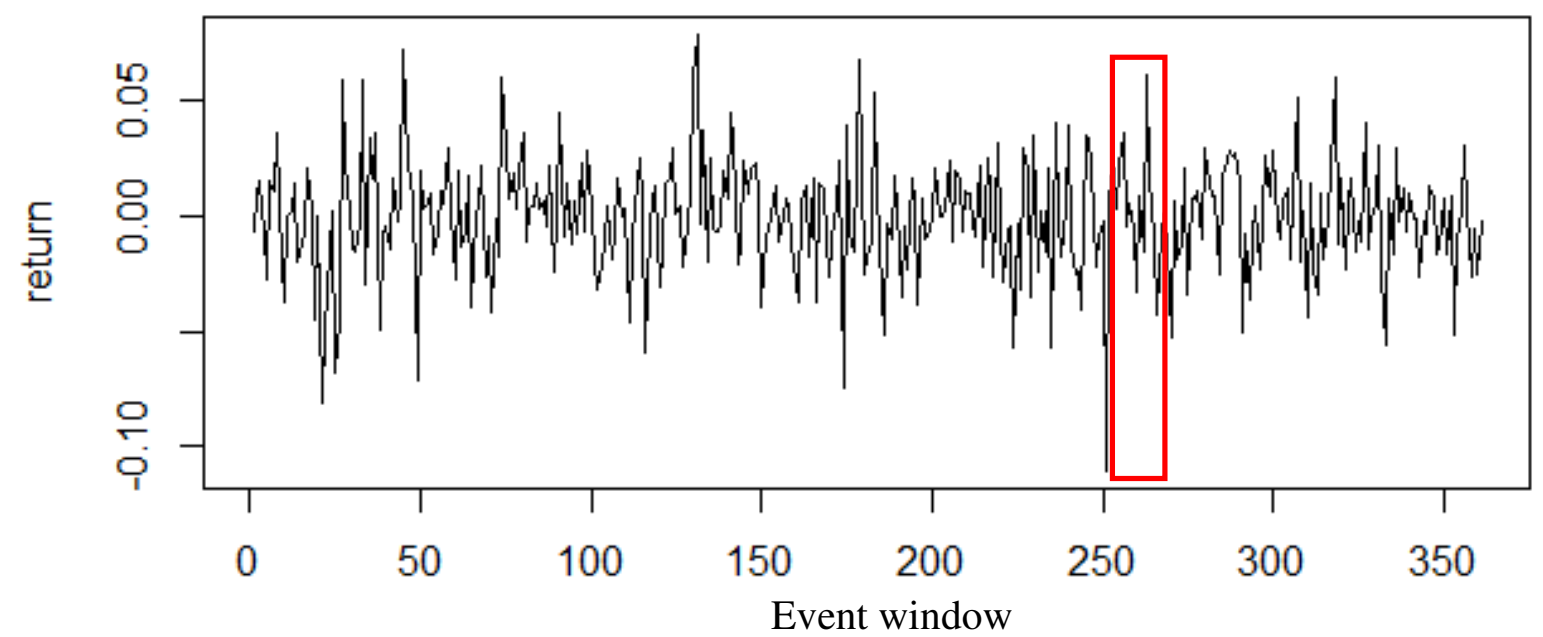

Fig2.Returns of return of PNB in merger with OBC and UB

When merger of ten banks were announced on the 30th of August 2019, only for IndianBank the $\alpha 1=0.310992$ and $\beta 1=0.305772$ were more or less equal which means the merger announcement had no impact on the stock. The figure below shows that the stock return of Bank of Baroda's plunged on the announcement day ( day 0) of its merger with Vijaya and Dena Bank on 1st September, 2018.

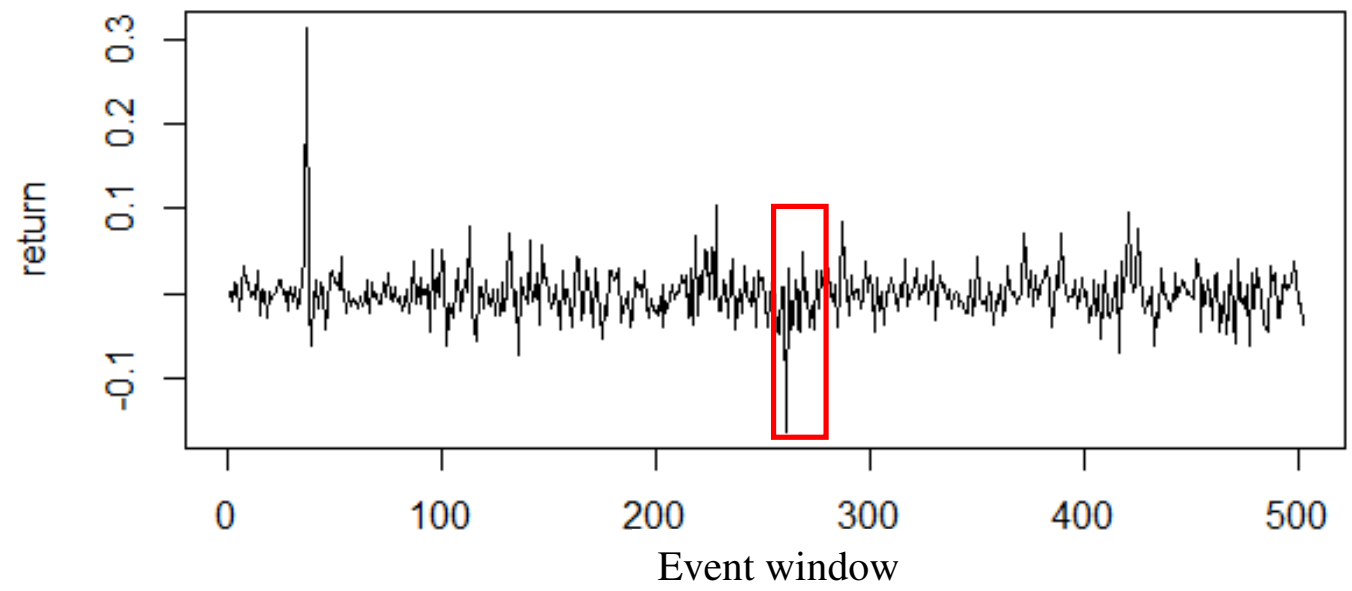

Fig 3.Returns of BOB on merger with Vijaya Bank and Dena bank

Only Indian Overseas Bank which merged with Bharat Overseas Bank has higher $\alpha 1$ value of 0.810165 which means that the volatility is very high and intense during the period and the announcement date has no impact on stock return. When the alpha vales are high and beta values 
are low then the spikes are high, the graph shows the persistence of volatility throughout the event period.

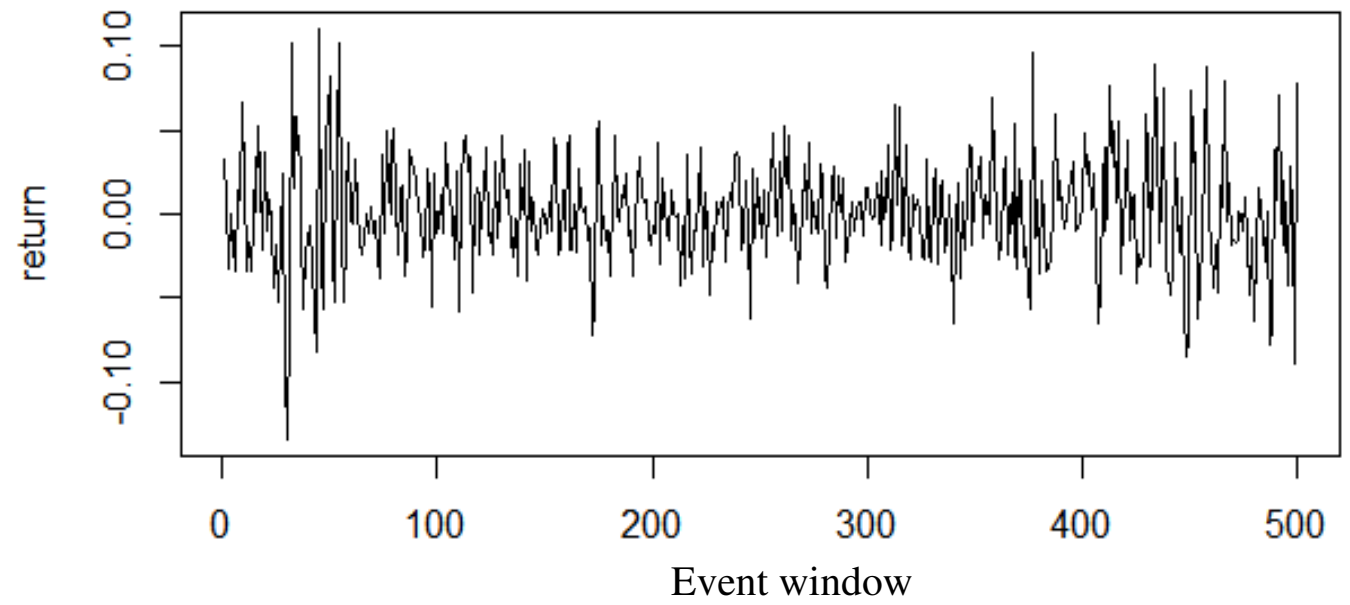

Fig 4.Indian Overseas Bank returns on merger with Bharat Overseas bank

From the above graph of Indian Overseas Bank returns it is seen that the stock price is affected by market movements throughout the event period and merger announcement does not have much impact on stock returns. The $\alpha 1$ (0.529437) during pre-merger announcement period is also higher than $\beta 1(0.204908)$ which is again a proof that the market movement has impact in the stock returns.

For mergers where the sum of the parameters (i.e) $\alpha 1+\beta 1$ is greater than 0.80 it implies that the volatility takes time to die, i.e. it would return to intend slowly. The table below shows the list of merger for which acquirer's bank stock return volatility reduces.

\begin{tabular}{|c|c|c|}
\hline Acquirer bank & Target bank & $\boldsymbol{\alpha 1 +} \boldsymbol{\beta 1}$ \\
\hline Oriental Bank of Commerce & Global Trust Bank & 1.00 \\
\hline IDBI Ltd & IDBI Bank & 1.00 \\
\hline Punjab National Bank & Nedungadi Bank Ltd. & 0.95 \\
\hline Federal Bank & Ganesh Bank of Kurandwad & 0.97 \\
\hline IDBI Ltd & United Western Bank & 0.89 \\
\hline ICICI Bank Ltd & Sangli Bank & 0.93 \\
\hline State Bank Of India & Swarastra Bank & 0.94 \\
\hline HDFC Bank & Centurion Bank of Punjab & 0.95 \\
\hline State Bank Of India & State Bank Of Indore & 0.98 \\
\hline ICICI Bank & Bank of Rajasthan Ltd. & 1.00 \\
\hline
\end{tabular}




\begin{tabular}{|c|c|c|}
\hline Kotak Mahindra Bank & ING Vyasa Bank & 1.00 \\
\hline State Bank of India & BMB,SBT, SBBJ,SBH,SBM, SBP & 0.90 \\
\hline Bank of Baroda & Vijaya bank, Dena bank & 0.95 \\
\hline Punjab National Bank & $\begin{array}{c}\text { Oriental Bank of Commerce \& United } \\
\text { Bank of India }\end{array}$ & 1.00 \\
\hline Canara Bank & Syndicate Bank & 1.00 \\
\hline Union Bank of India & Andhra Bank \& Corporation Bank & 1.00 \\
\hline
\end{tabular}

Table 2.List of merger with acquirer's bank $\alpha 1+\beta 1$ is greater than 0.80

It is seen that the announcement of merger of SBI with associate - Indore has a positive influence as there is spike in stock price during the days near the announcement of merger. Even though volatility persists during pre- merger period there is sudden positive return during the event day. The value of $\alpha 1+\beta 1=0.98$ and then it is dying down slowly after few days.

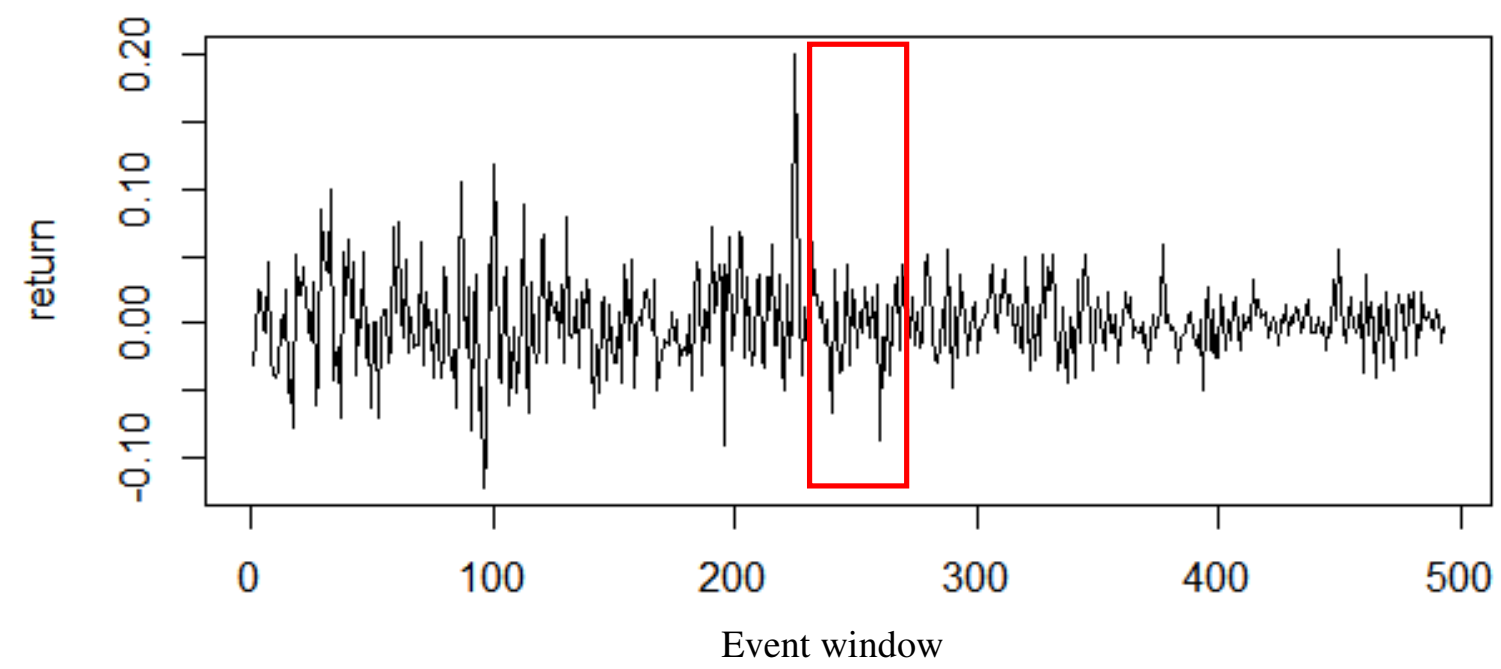

Fig 5. Returns of State bank of India while merging with state bank of Indore

As seen above majority of acquirer bank's stock price become highly volatile on the announcement of merger and acquisition of banks. The acquirer banks have higher $\beta 1$, hence the volatility is 'persistent'. When $\beta 1$ is notably higher than $\alpha 1$ then there are higher volatilities. Hence it is proved that the merger impacts the volatility of stock return of acquirer banks 


\section{Findings \& Discussions}

In this study, it is seen that when the merger of Oriental bank of commerce's with GTB was announced the Oriental bank of commerce stock on NSE opened at 263 but showed very high volatility on the announcement day with a High of 283 and Low of 247. This is also proved by the GARCH model as $\alpha 1+\beta 1$ is greater for Oriental bank of commerce.

Among the recent merger announcement of public sector banks, all 4 acquirer banks the PNB, $\mathrm{CB}$, UB and IB shows high volatility with $\alpha 1+\beta 1$ close to 0.999 . The investors could make use of these stocks to earn higher returns if invested at the right time. The SBI merger with associates in 2016 also shows high volatility with $\alpha 1+\beta 1=0.90$, as soon as the merger was announced there was positive impact with a $3 \%$ increase to Rs.377 in NSE, which is similar to finding of Khan and Zia (2018).

With this study, attempt has been made to contribute to the understanding of effects on stock price due to unexpected merger announcements. With the new information being introduced, it would be expected that there would be increased volatility within the event period.

The Merger and acquisition events in banking sector are responsible for jumps in volatility in post-event period in different ways. The results of present study are in consensus with findings by Pessanha et al. (2016); Kamar (2016), and Louhichi (2008)

Majority of the acquirer's bank stock price is affected by the merger announcement. This study helped us to understand the speed with which the market reacts to information. An investor may use this idea to earn greater returns against the market

\section{Conclusion}

The study evaluated the volatility of the stock return around merger announcement of banks in India using GARCH $(1,1)$ model. The results proved the increase in stock volatility. In particular, the results demonstrate that acquiring banks do not suffer any loss and implies that Mergers are not risky for the shareholders of those acquiring banks.

The return volatility is high on the event day. The volatility spread is observed to be existing during the event period but the spread of returns is normal and positive after the merger announcement.

In this paper only, volatility of stock returns based on the announcement of merger and acquisition were studied. Other factors such as Profitability, efficiency and performance of banks after merger were not analyzed. In order to get true picture of the benefits of mergers to investors these factors that affects the bank financial performance can also be analyzed. The future research can use long-term data, as only 500-day period was studied. For few banks which have announced merged recently (i.e) in 2019, 500day event window were not considered as the number of days post announcement was less.

\section{References}

[1]. Bhattacharyya, S., \&Chatri, A. (2012). Efficiency of Indian Commercial Banks: The Post-Reform Experience from Mergers and Acquisitions. The Indian Economic Journal, 60(3), 3-28. 
[2]. Caiazza, S., Pozzolo, A. F., \&Trovato, G. (2014). Do domestic and cross-border M\&As differ? Crosscountry evidence from the banking sector. Applied Financial Economics, 24(14), 967-981.

[3]. Dirk, S. et al (2009), "Investment Bank Reputation and Shareholder Wealth Effects in Mergers and Acquisitions", Research In International Business and Finance, 23, 257-273

[4]. Khan, A. A. (2011). Merger and Acquisitions (M\&As) in the Indian banking sector in post liberalization regime. International Journal of Contemporary Business Studies, 2(11), 31-45.

[5]. Khan, A. A., \&Ikram, S. (2012). Testing the efficiency of Indian stock market Vis-À-Vis merger and acquisitions-A Study of Indian Banking Sector. International Journal of Latest Trends in Finance and Economic Sciences, 2(2), pp.155-168.

[6]. Khan, A., \& Zia, A. (2019). Market volatility of banking stock return vis-à-vis banks merger: An application of GARCH model. Management Science Letters, 9(5), 629-638.

[7]. Kumar, M., Kumar, S., \&Deisting, F. (2013). Wealth effects of bank mergers in India: a study of impact on share prices, volatility and liquidity. Banks and Bank Systems,Vol. 8 No.1, 127-133.

[8]. Kuriakose, S., \& Paul, J. (2016). Strategic and financial similarities of bank mergers. Review of International Business and Strategy, Vol. 26 No. 1, pp. 50-68.

[9]. Louhichi, W. (2008). Adjustment of stock prices to earnings announcements: Evidence from euronext Paris. Review of Accounting and Finance, Vol.7 No.1, 102-115 Mall, P., \& Gupta, K. (2019). Impact of mergers on stock performance and risk of acquiring firms: Evidence from India. Drishtikon: A Management Journal, 10(1), 27-46.

[10]. Mueller, C.D., Sirower, L.M., (2003), "The causes of mergers: Tests based on the gains to acquiring firms' shareholders and the size of premia", Managerial and Decision Economics Vol. 24 No.5, pp373391

[11]. Patel, R. \&Shah,D.( 2016), Mergers and Acquisitions: A Pre-post Risk and Return Analysis for the Indian Banking Sector, Journal of Applied Finance \& Banking, SCIENPRESS Ltd, vol. 6, No.3, pp 1-7.

[12]. Pessanha, G. R. G., Bruhn, N. C. P., Calegario, C. L. L., Sáfadi, T., \&Ázara, L. N. D. (2016). Mergers and Acquisitions and Market Volatility of Brazilian Banking Stocks: An Application of GARCH Models. Latin American Business Review, 17(4), 333-357.

[13]. Radha Naga and Tabassum (2013), Financial performance analysis in Banking sector- A Pre \& Post Merger perspective, ABHINAN, Vol,2, pp56-66

[14]. Rani, N., Yadav, S. S., \& Jain, P. K. (2015). Financial performance analysis of mergers and acquisitions: Evidence from India. International Journal of Commerce and Management, Vol.25, No.4,pp. 402-423

[15]. Rao, S. D., \& Kumar, R. P. (2013). Financial performance evaluation of Indian commercial banks during before and after mergers. Sumedha Journal of Management, 2(1), 117.

[16]. Sahni, D., \&Gambhir, S. (2018). Financial performance evaluation of Indian commercial banks after merger and acquisition. Gurukul Business Review, 14, 26-36.

[17]. Schiereck, D., Sigl-Grüb, C., \&Unverhau, J. (2009). Investment bank reputation and shareholder wealth effects in mergers and acquisitions. Research in International Business and Finance, 23(3), 257-273.

[18]. Shah, A., \&Deo, M. (2013). BANK MERGERS AND SHAREHOLDER VALUE CREATION IN INDIA. International Journal of Business \& Society, 14(2).

[19]. Singh, G., \& Gupta, S. (2015). An impact of mergers and acquisitions on productivity and profitability of consolidation banking sector in India. Abhinav International Monthly Refereed Journal of Research in Management \& Technology, 4(9), 33-48.

[20]. Singh, S., \& Das, S. (2018). Impact of post-merger and acquisition activities on the financial performance of banks: A study of Indian private sector and public sector banks. RevistaEspacios Magazine, 39(26), 25.

[21]. Slimane, F. (2012), Stock exchange consolidation and return volatility, Managerial Finance, Vol. 38 No. 6, pp. 606-627. 
[22]. Tan, H. B., \&Hooy, C. W. (2004). Bank merger and bank stock volatility: a post $\square$ announcement analysis. Managerial Finance, 30(4), pp.29-47.

[23]. Tandon, N., Saxena, N., \&Tandon, D. (2019). The Merger of Associate Banks with State Bank of India: A Pre-and Post-Merger Analysis. IUP Journal of Management Research, 18(1), 123-134.

[24]. Tanwar, N. (2016). A Study on the performance analysis of banks in India after mergers and Acquisitions. International Journal of Commerce and Management Research, 2, 37-40. 